\title{
Applications of natural essential oils as antibacterial for archaeological organic materials
}

\author{
Ali, M. O. ${ }^{1}$, Taha, A. S. ${ }^{2^{*}}$,AboElgat, W. A. A. ${ }^{3}$, Fatma, E .L. ${ }^{4}$ \\ ${ }^{1}$ Microbiology Department, Conservation Center, Grand Egyptian Museum, Egypt \\ ${ }^{2}$ Conservation Department, Faculty of Archaeology, Aswan University, Aswan 81528, Egypt; \\ ${ }^{3}$ Restoration Department, High Institute of Tourism, Hotel Management and Restoration, Abukir, \\ Alexandria 21526, Egypt; \\ ${ }^{4}$ National Museum of Civilization, Ministry of Torism and Antiquities, Egypt. \\ * Corresponding auther: aymansalahtaha82@yahoo.com
}

\begin{abstract}
Cultural heritage materials degrades over time, however conservation slows down the speed of its deterioration. Microbiological contamination with bacteria can pose a big destroy to old manuscripts and mummy or hazard to those working in archives or library.Most of the biological damage is started in poor environmental conditions for storage and display. The gas chromatography/mass spectrometry (GC/MS) analysis of the oils revealed the main constituents of the essential oils Eucalyptus camaldulensis, spathulenol (20.84\%), eucalyptol (12.01\%), sabinene (9.73\%), $\alpha$ phellandrene $(8.18 \%)$, crypton $(7.69 \%)$, terpinen-4-ol $(3.69 \%)$, phellandral $(3.54 \%)$ and D-limonene (2.28\%), and Citrussinensis, D-limonene (73.4\%) and -terpinene (22.6\%).

This work aimed to access the presence of microorganisms and their effect on the old manuscripts, mummy deterioration; it also studies their treatment methods, such as fumigation natural oils. The causes of the various efficacy of the treatments are observed, also because the potential risks of recolonization by viable cells left behind after treatment. The results further showed that the test oils were able to inhibit the mycelia growth by usingthe fumigation method.The potent properties of $E$. camaldulensis, the possibility of using it as eco-friendly, safe, and cost-effective antibacterials for bacterial that could cause discoloration of the archaeological organic materials.
\end{abstract}


Keywords:Essentialoils, Fumigation, Deterioration, Microbiological, Antibacterial, Treatment.

\section{Introduction}

Antibiotics are one of our most significant to bacterial and fungal decay and have greatly benefited the health-related quality of human life since their introduction. The problem of microbial resistance is increasing for the use of antimicrobial medication in the future is still uncertain. Therefore, actions must resolve this problem, for example, to control the use of antibiotic, develop research to better understand the original mechanisms of resistance, and to continue studies to develop novel soporific, either artificial or natural. The extreme aim is to offer suitable and active antimicrobial real estate to the patient. $[1,2]$. For a long period of time, plants have been a precious source of natural products for use in the medical domain, principally in the last time, with more strong studies for natural treatment. The use of plant extracts for curative objective has progressively increased in Brazil.

According to World Health Organization [3] curative plants would be the better source to procure a assortment of soporific Plants are wealthy in a broad variety of secondary metabolites such as tannins, terpenoids, alkaloids, flavonoids, glycosides, etc., which have been found in vitro to have antimicrobial characteristic [4,5].The World Health Organization estimates that plant extracts are used as people medicine in conventional treatment of $80 \%$ of the world's population [6].The felled microorganisms can be prevented with realty and these results in the germination of various medicament renitent bacteria and it has created terrible clinical condition in the controlling of contamination[7,8]. The performance of civilization of Ancient Egypt was indebted to the Nile River. Moreover, watery plants confer with a spacious set of capitalize to human being and form one of the wealthy ecological units in Egypt[9]. There are 25 families of watery plants subdivided into 45 genera and 87 species of effloresce plants in the Nile River[10-14]. The antimicrobial properties of water plants are owed to a variety of 
INTERNATIONAL JOURNAL OF

ADVANCED SCIENTIFIC RESEARCH AND INNOVATION

VOLUME 2, ISSUE 2, 2021, $8-25$.

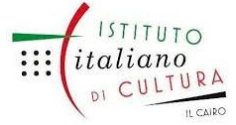

www.egyptfuture.org

/ojs/

secondary metabolites such as alkaloids which have been found in firm floating leaved species, whereas submerged species contain both simple phenols and flavonoids $[15,16]$.

The antimicrobial properties of plants have been inspected, by a number of researchers, especially in Latin America.In Argentina, a search tested 122 best-known plant species used for therapeutic treatments[17].

It have been documented that a lot of the compounds extracted from those plants, twelve stifled presence of Staphylococus aureus, ten stopped Escherichia coliand 4 inhibited Aspergillus niger and moreover confirmed that the preliminary effective compound become one extracted from Tabebuiaimpetiginosa [18].The chemical compositions of the extracts could be analyzed and examination by wherewithal of gas chromatographye mass spectrometry (GC/MS) technique[ 19]. Orange fruits are typically refers to Citrus sinensis (belongs to Rutaceae family) or Sweet Orange Group.The EO extracted from orange peels can be used as a green insecticide and have potential effects against microbes[20 - 24].Therefore, the aim of this study was to evaluate the antibacterial activity of the EOs from E. camaldulensis and Citrus sinensis against the growth of bacterial strains isolated from organic materials.

\section{Materials and Methods}

\subsection{Collection of Swabs:}

Swabs were obtained from degraded mummy at the grand Egyptian museum and rare books for the parliament of the Arab Republic of Egypt. We make examination for a similar books under (Description DeI'Egypte- Tome 1- 5 - Antiquities Descriptions) from the examination we found that most of books suffer from severe microbial infections, which are manifested in the presence of clear microbial lesions in the form of brown spots, which have been combined in many pages of books to cover the entire pages in brown color, To change the color of some pages to brown colormicrobial swabs were cultured on (Cellulose, Protein and Nutrient agar media). 
INTERNATIONAL JOURNAL OF

ADVANCED SCIENTIFIC RESEARCH AND INNOVATION

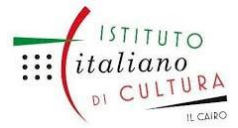

www.egyptfuture.org

ISSN: 2785-9541

VOLUME 2, ISSUE 2, 2021, 8-25.

/ojs/

\subsection{Isolation of Microorganisms and Growth Media:}

The antibacterial contaminants wereisolated from the infected archaeological objects which characterized according to molecular approach by using sequencing of rRNA and ITS region of rDNA gene at Solgent Company, South Korea.

The following genera were identified: Micrococcus luteus (MH450098), Microbacteriumschleiferi (NR044936T), Bacillus subtilis (NR112629T).Other microorganisms isolated from degraded mummy. The following genera were identified: based on ribosomal RNA analysis, to bacteria found in the human skin microbiome

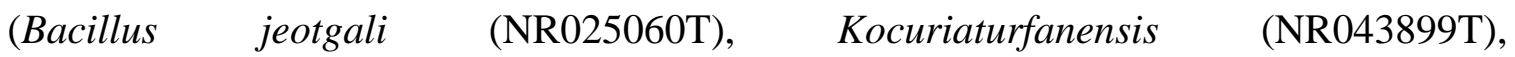
Microbacteriumimperial (NR026161T), \&Bacillus megaterium( NR112636T). The bacterial stock cultures were incubated for 24 hours at $37^{\circ} \mathrm{C}$ on nutrient agar medium. The stock cultures were maintained at $4^{\circ} \mathrm{C}$.

\subsection{Essential Oils Extraction:}

Fresh leaves of Cimumbasilicumand fresh peels of Citrus sinensiswere collected during January 2020, from Alexandria, Egypt. These raw materials were cut to small pieces and were hydro-distillated for $3 \mathrm{~h}$. in a Clevenger apparatus[25- 28]. The essential oils (EOs) were dried over anhydrous $\mathrm{Na}_{2} \mathrm{SO}_{4}$. The collected EOs were stored in brown glass bottles in a refrigerator at $4^{\circ} \mathrm{C}$.

\subsection{Preparation of essential oils:}

The extracted EOs were prepared at the concentrations of1000, 2000, 4000 and 5000 ppm . The respective amount of oil was diluted in a dimethyl sulfoxide (DMSO 10\%), SDW $(1: 1 v / v)$ and $0.5 \mathrm{ml}$ of Tween 40 was added.

\subsection{GC/MS analysis of Essential Oils:}

The chemical components of the EOs from E. camaldulensis fresh leaves and $C$. sinensis fresh peels clean peels have been carried out using GC-TSQ Quantum mass spectrometer (Thermo Scientific, Austin, TX, USA) with an immediate capillary column TG-5MS $(30 \mathrm{~m} \times 0.25 \mathrm{~mm} \times 0.25 \mu \mathrm{m}$ film thickness $)$. The conditions of the separation and identification of the EOs can be found in the previous works [19, 26-30]. 
INTERNATIONAL JOURNAL OF

ADVANCED SCIENTIFIC RESEARCH AND INNOVATION

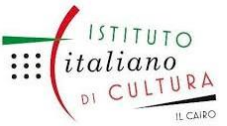

www.egyptfuture.org

ISSN: 2785-9541

VOLUME 2, ISSUE 2, 2021, 8-25.

/ojs/

\subsection{Antibacterial activity:}

\subsubsection{Determination of inhibition zones method:}

Antibacterial activities of natural oils (E. camaldulensis, and C. sinensis) against the isolated microorganisms were tested using the agar diffusion method. The bacterial cultures were incubated for 24 hours at $37^{\circ} \mathrm{C}$ on nutrient agar medium. The zones of development inhibition around the wells have been measured after 18 to 24 hours of incubation at $37^{\circ} \mathrm{C}$. The sensitivities of the microorganism species to the natural oils had been determined through the sizes of inhibition zones (inclusive of the diameter of the well) on the agar surface around the wells. Values $<15$ millimeters have been taken into consideration as no longer active in opposition to microorganisms [31,32].combination of $10 \%$ DMSO and SDW $(1: 1 \quad \mathrm{v} / \mathrm{v})$ became used as an alternative within the control pattern.

\subsubsection{Determination of minimal inhibitory concentration (MIC) of natural oils:}

A stock solution of each microcide of natural oils were prepared by dissolving 1.0 $\mathrm{ml}$ of each natural oils in one letter of $10 \%$ DMSO .Gradient concentrations of natural oils(1000, 2000, 4000 and $5000 \mathrm{ppm})$ were prepared by using 10\% DMSO+ drops of Twen40. $1 \mathrm{ml}$ of bacterial spore suspension was spread on a nutrient agar plate. The plates were allowed to dry, then a cork purer was used to make three pores (about $15 \mathrm{~mm}$ in diameter) to make three replecates. On one plate, $100 \mu 1$ of each concentration $(1000$, 2000, 4000 and $5000 \mathrm{ppm}$ ) of the tested oil were placed. The plates were incubated at $30^{\circ} \mathrm{C}$ for $24 \mathrm{~h}$ compared with control plates (10\% DMSO).

The MIC was determined by measuring the sizes of inhibitory zones (including the diameter of the well) on the agar surface around the wells; values <15 mm were considered as not active against microorganisms. The MIC was determined by measuring the inhibition zone according toprevious papers [37,38]. MIC test is the gold standards for deciding the susceptibility of organisms to a specific antimicrobial 
INTERNATIONAL JOURNAL OF

ADVANCED SCIENTIFIC RESEARCH AND INNOVATION

VOLUME 2, ISSUE 2, 2021, 8-25.

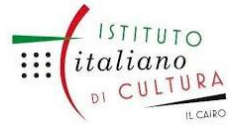

www.egyptfuture.org

/ojs/

substance so accustomed decide the performance of all different strategies of susceptibility testing[39].

\section{Determination of the effectiveness of oils in the elimination of bacterial infections by} using the fumigation method.

Treatment of the infected books was applied by a fumigation method with natural oils (Eucalyptus camaldulensis) at (5000 ppm/L) was prepared by dissolving $5 \mathrm{ml} / \mathrm{L}$ in $10 \%$ DMSOto prevent microbial growth for 6 months. Microbial growth was examined by taking of swabs from each treated specimen after 48 hours, 3 months and 6 months.

\section{Results and discussion:}

\subsection{Bacterial activity}

All tested bacterial isolates, Micrococcus luteus, Microbacterium schleiferi, Bacillus subtilis,Bacillus jeotgali ,Kocuria turfanensis, Microbacterium imperial and Bacillus megaterium were isolated from archaeological objects. Antimicrobial activities of natural oils were assessed in terms of zone inhibition of microorganism growth. The results are presented in table.1 showing that Citrus sinensis E.Oil has good sensitive to the some tested microorganisms, butEucalyptus camaldulensisE.Oilhas good sensitive against all tested microorganisms .

Table 1.Diameter of inhibition zones in $(\mathrm{mm})$ due to natural oils.

\begin{tabular}{|c|c|c|}
\hline Microbial strains & \multicolumn{2}{|c|}{ Natural oils } \\
\hline & Eucalyptus camaldulensis & Citrus sinensis \\
\hline Micrococcus luteus & $30 \mathrm{~mm}$ & $25 \mathrm{~mm}$ \\
\hline Kocuria turfanensis & $25 \mathrm{~mm}$ & $20 \mathrm{~mm}$ \\
\hline Bacillus megaterium & $20 \mathrm{~mm}$ & $18 \mathrm{~mm}$ \\
\hline $\begin{array}{c}\text { Microbacterium } \\
\text { schleiferi }\end{array}$ & $27 \mathrm{~mm}$ & $-\mathrm{ve}$ \\
\hline Bacillus subtilis & $25 \mathrm{~mm}$ & $-\mathrm{ve}$ \\
\hline Bacillus jeotgali & $30 \mathrm{~mm}$ & $-\mathrm{ve}$ \\
\hline $\begin{array}{c}\text { Microbacterium } \\
\text { imperial }\end{array}$ & $24 \mathrm{~mm}$ & $-\mathrm{ve}$ \\
\hline
\end{tabular}


INTERNATIONAL JOURNAL OF

ADVANCED SCIENTIFIC RESEARCH AND INNOVATION

VOLUME 2, ISSUE 2, 2021, $8-25$.

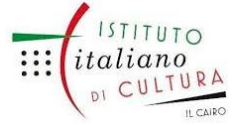

www.egyptfuture.org /ojs/

\subsection{Determination of minimal inhibitory concentration (MIC) of natural oils:}

In this experiment, the prepared natural oils applied to the tested bacteria to determine the MIC that inhibited each bacterial species proved, good response could be detected at concentration $5000 \mathrm{ppm}$ gave the diameter of a clear zone ranged (18-25 mm) afterwards $24 \mathrm{~h}$ at $37{ }^{\circ} \mathrm{C}$. but the other concentrations that gave no response in all isolates. But in case of Citrus sinensis natural oils that gave no response in all isolates at in all concentrations.

Table 2.Means of inhibition zones (mm) of essential oils (E. camaldulensis and $C$. sinensis ) at different concentrations (ppm).

\begin{tabular}{|c|c|c|c|c|c|c|c|c|c|c|}
\hline \multirow[t]{3}{*}{ Microbial strains } & \multicolumn{10}{|c|}{ concentration of natural oils (ppm) } \\
\hline & \multicolumn{5}{|c|}{ Eucalyptus camaldulensis } & \multicolumn{5}{|c|}{ Citrus sinensis } \\
\hline & control & 1000 & 2000 & 4000 & 5000 & control & 1000 & 2000 & 4000 & 5000 \\
\hline $\begin{array}{c}\text { Micrococcus } \\
\text { luteus }\end{array}$ & 0.00 & 0.00 & 0.00 & 0.00 & 20 & 0.00 & 0.00 & 0.00 & 0.00 & 0.00 \\
\hline $\begin{array}{l}\text { Kocuriaturfanen } \\
\text { sis }\end{array}$ & 0.00 & 0.00 & 0.00 & 0.00 & 25 & 0.00 & 0.00 & 0.00 & 0.00 & 0.00 \\
\hline $\begin{array}{c}\text { Bacillus } \\
\text { megaterium }\end{array}$ & 0.00 & 0.00 & 0.00 & 0.00 & 19 & 0.00 & 0.00 & 0.00 & 0.00 & 0.00 \\
\hline $\begin{array}{c}\text { Microbacteriums } \\
\text { chleiferi }\end{array}$ & 0.00 & 0.00 & 0.00 & 0.00 & 20 & 0.00 & 0.00 & 0.00 & 0.00 & 0.00 \\
\hline Bacillus subtilis & 0.00 & 0.00 & 0.00 & 0.00 & 23 & 0.00 & 0.00 & 0.00 & 0.00 & 0.00 \\
\hline Bacillus jeotgali & 0.00 & 0.00 & 0.00 & 0.00 & 18 & 0.00 & 0.00 & 0.00 & 0.00 & 0.00 \\
\hline $\begin{array}{c}\text { Microbacterium } \\
\text { imperial }\end{array}$ & 0.00 & 0.00 & 0.00 & 0.00 & 21 & 0.00 & 0.00 & 0.00 & 0.00 & 0.00 \\
\hline
\end{tabular}

\subsection{Chemical composition of the natural oils:}

As mentiond in our previous study [27] Fig. (1), the major chemical compounds in $E$. camaldulensis EO, spathulenol (20.84\%), eucalyptol (12.01\%), sabinene (9.73\%), $\alpha$ phellandrene $(8.18 \%)$, crypton $(7.69 \%)$, terpinen-4-ol (3.69\%), phellandral $(3.54 \%)$.Table 


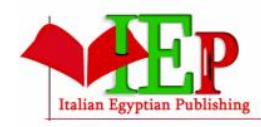

ISSN: 2785-9541
INTERNATIONAL JOURNAL OF

ADVANCED SCIENTIFIC RESEARCH AND INNOVATION

VOLUME 2, ISSUE 2, 2021, $8-25$.

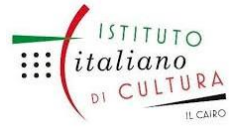

www.egyptfuture.org

lojs/

3 and $D$-limonene (2.28\%).D-limonene (73.4\%) and $\gamma$-terpinene (22.6\%) were the abundant compounds in the EO from $C$. sinensispeels. Table 4.

Table 3.Phytochemical composition of E. camaldulensis essential oil by GC/MS.

\begin{tabular}{|c|c|c|c|}
\hline RT (min.) & Compound & Percentage in the Oil (\%) & RSI-SI * \\
\hline 6.68 & 2-Thujene & 1.12 & $(944-905)$ \\
\hline 6.98 & $\grave{\alpha}$-Pinene & 1.14 & $(938-919)$ \\
\hline 8.63 & $\grave{\alpha}$-pinene & 0.77 & $(931-897)$ \\
\hline 9.44 & $\grave{\alpha}$-Phellandrene & 8.18 & $(939-938)$ \\
\hline 9.70 & 4-Terpinenyl acetate & 0.38 & $(913-882)$ \\
\hline 10.10 & D-Limonene & 2.28 & $(924-916)$ \\
\hline 10.39 & Sabinene & 9.73 & $(940-936)$ \\
\hline 10.53 & p-Cymene & 15.16 & $(923-906)$ \\
\hline 10.68 & Eucalyptol & 12.01 & $(921-902)$ \\
\hline 11.16 & $\gamma$-Terpinene & 1.09 & (919-879) \\
\hline 12.06 & (E) - $\grave{\alpha}$-Ocimene & 0.7 & $(871-860)$ \\
\hline 14.11 & cis-B-Terpineol & 0.64 & $(918-885)$ \\
\hline 14.87 & cis-para-2-menthen-1-ol & 0.38 & $(913-863)$ \\
\hline 16.11 & Terpinen-4-ol & 3.69 & $(928-923)$ \\
\hline 16.83 & $\grave{\alpha}$-Terpineol & 0.42 & $(869-853)$ \\
\hline 17.85 & Crypton & 7.69 & $(952-932)$ \\
\hline 19.36 & Cuminaldehyde & 1.81 & $(949-855)$ \\
\hline 20.19 & Phellandral & 3.54 & $(952-884)$ \\
\hline 20.94 & 2-ethylidene-6-methyl-3,5-Heptadienal & 1.54 & $(823-807)$ \\
\hline 23.61 & Aromadendrene & 1.71 & $(932-847)$ \\
\hline 24.85 & Nerolidyl acetate & 0.41 & $(797-787)$ \\
\hline 27.59 & Spathulenol & 20.84 & $(947-922)$ \\
\hline 28.26 & 2-Methylene-5_-cholestan-3_-ol & 0.41 & $(843-781)$ \\
\hline 28.54 & Linoleic acid ethyl ester & 1.65 & $(743-735)$ \\
\hline 28.82 & Oleic acid & 0.27 & $(808-792)$ \\
\hline 29.06 & $\grave{\alpha}$-Vetivol & 1.12 & $(772-759)$ \\
\hline 29.23 & $\grave{\alpha}$-Sinensal & 0.21 & $(793-759)$ \\
\hline 29.54 & (Z,Z)-1,3-Dioctadecenoyl glycerol & 0.17 & $(836-816)$ \\
\hline 29.77 & (11Z)-12-(2-Oxiranyl)-11-dodecenyl acetate & 0.18 & $(805-766)$ \\
\hline
\end{tabular}

Table 4.Phytochemical composition of $C$. sinensisessential oil by GC/MS.

\begin{tabular}{|l|l|l|l|}
\hline RT (min.) & Compound & Percentage in the Oil (\%) & RSI-SI $*$ \\
\hline
\end{tabular}


INTERNATIONAL JOURNAL OF

ADVANCED SCIENTIFIC RESEARCH AND INNOVATION

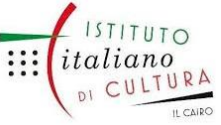

www.egyptfuture.org

ISSN: 2785-9541

VOLUME 2, ISSUE 2, 2021, 8-25.

/ojs/

\begin{tabular}{|c|c|c|c|}
\hline 8.57 & Myrcene & 1.13 & (952-944) \\
\hline 10.13 & D-Limonene & 73.4 & (945-944) \\
\hline 10.46 & p-Cymene & 1.02 & $(923-840)$ \\
\hline 11.13 & $\gamma$-Terpinene & 22.6 & $(950-949)$ \\
\hline 16.74 & $\grave{\alpha}-$ Terpineol & 0.81 & $(931-923)$ \\
\hline 29.42 & Ylangenal & 1.04 & $(803-783)$ \\
\hline
\end{tabular}

RT: Retention time (min.); * (RSI: Reverse Standard index; SI: Standard Index)

\subsection{Determine the appropriate method for bacterial treatment of pathogenic organisms:}

There are various methods that can be used for applying the microbial treatment to the books by using the MIC of natural oils E. camaldulensis at concentration $5000 \mathrm{ppm}$. These methods differ based on the condition of the books. The authors declare that there is no conflict of interest specific techniques were used for this purpose brushing method, sparing method and fumigation method. the first and second approach were carried out in a small scale, however the third technique was carried out to the book inside the sealed tight cabinet. After the examine, we found the suitable method to apply the treatment of oils is the approach of fumigation within the area of tightly sealed.these so-known as " fumigation " techniques require the use of sealed chambers, and are sometimes a great alternative to microcides. Eucalyptus camaldulensis vital oil had activity towards the bacteria. however, the antibacterial activity of crude vital oil varied among the test pathogens. The findings of the current study concur with reports from previous studies on different levels of antibacterial activity of vital oil of E. camaldulensis of varied chemical profiles against a various group of plant pathogenic bacteria[40]. 

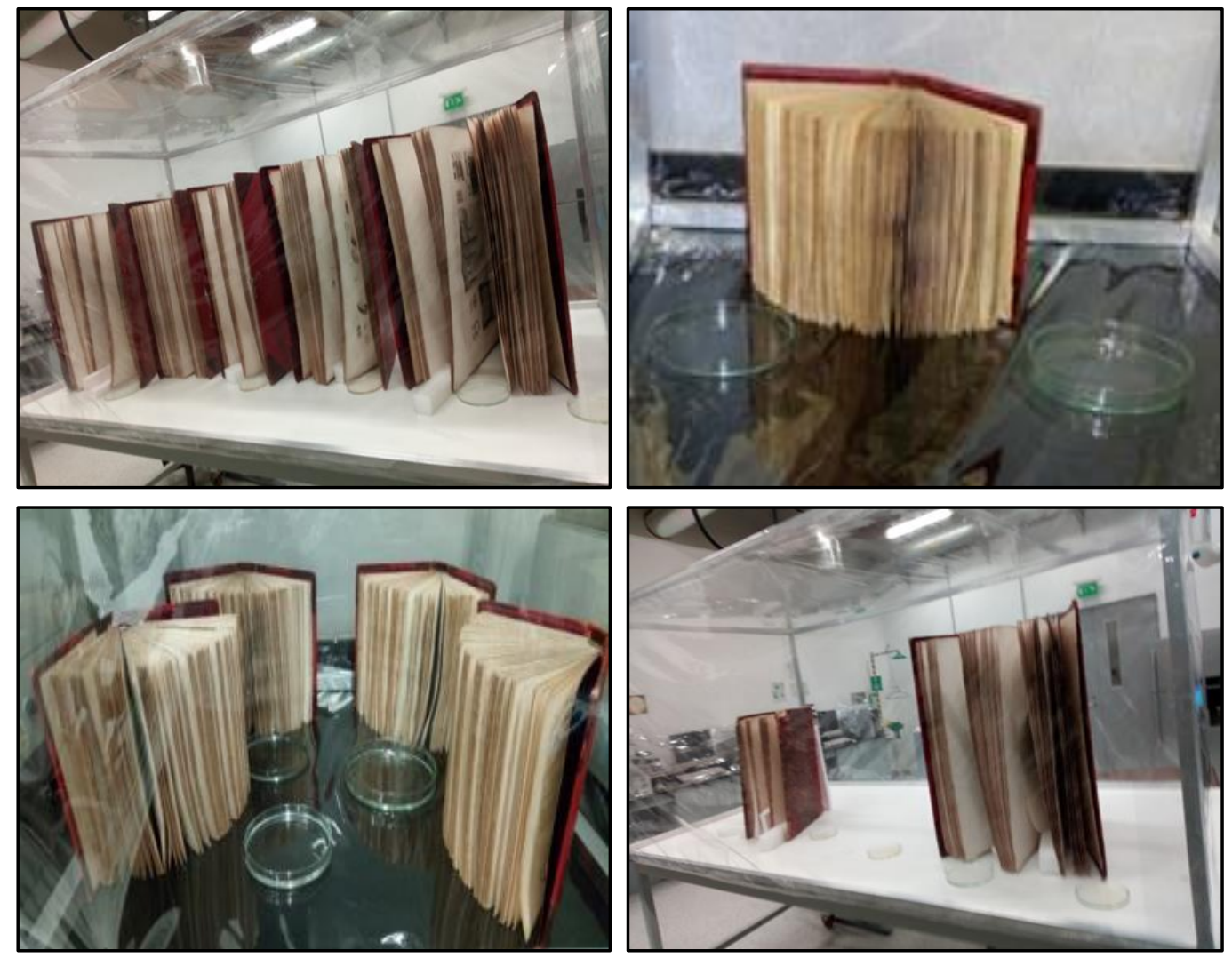

Fig.1:Showing Fumigation methods to applying the microbial treatments of natural oils.

\section{Discussion}

Testing and proving of biological activity of EOs is one of the main objectives of the study of natural materials. It is now popular through all the scientific community that these research must be aware of the variability of the biological material concerned. In reality, it is known that the composition of EOs can be distinctive due to the species, the agro-ecological components and the part of the plant that's being analysed [41].results of the study show the considerable values of antibacterial activity of essential oils (EOs) of Eucalyptus camaldulensis air-dried aerial parts, Citrus aurantium leaves, and $C$. sinensis peels against microbials singly and in combination together with equal volume. The occurred results are due to presence of components inclusive of spathulenol, p-cymene, eucalyptol, linalyl 
INTERNATIONAL JOURNAL OF

acetate, linalool, sabinene, phellandrene, crypton, terpinen-4-ol, D-limonene, terpinene, terpineol, longifolene, neryl acetate, p-cymene, phellandral cuminaldehyde, and alloaromadendrene in the Eos [42,43]. The EO from aerial parts of $E$. camaldulensis showed the presence of p-cymene (27.8-42.7\%), 1,8-cineole (4.1$39.5 \%)$, spathulenol (2.1-15.5\%), and cryptone (3.2-10.2\%) as main compounds[44].The EOs with their chemical compositions of 1,8-cineole (60\%), aromadendrene (_5\%), and limonene $(\geq 4 \%)$ or p-cymene $(10 \%), \beta$-pinene $(8 \%)$ and spathulenol (10\%), were characterized some E. camaldulensisclones grown in Australia [45]. p-Cymene, cyptone, and spathulenol with $22.9 \%, 14.1 \%$, and $16.5 \%$, respectably, were found to be the abundant compounds of E. camaldulensis EO from Australia [46].1,8-Cineole (34.7\%), $\beta$-pinene (7.7\%), p-cymene (9.3\%), and spathulenol (9.5\%) were reported as main compounds in EO of E. camaldulensis from Greece [47]. E. camaldulensis leaf EO with its principal compounds eucalyptol, $\beta \quad$-pinene, and terpinene carried out to wood showed accurate inhibition towards microbial[19]. For the usually common mechanisms of antimicrobial interaction that produce synergism, it was found that the combinations of EOs led to inhibition of the common biochemical pathway with inhibition of the protective enzymes, with subsequent use of cell wall-active agents to enhance theuptake of other antimicrobials [48, 49].which is related to the presence of phenolic compounds such as p-hydroxy benzoic acid, gallic acid, salicylic acid, and caffeine. E. camaldulensisbooks treated has shown antibacterial activities with a high content of quercetin, benzoic acid, naringenin, caffeine, o-coumaric acid, and kaempferol [50].

\section{Conclusion}

The findings have shown the potential of natural oil only with bacteria, but when we diluted with the solvent gave no response in all isolates. Therefore, it could be reported that using natural oils (E. camaldulensis) at $(5000 \mathrm{ppm})$ was sufficient to 
INTERNATIONAL JOURNAL OF

ADVANCED SCIENTIFIC RESEARCH AND INNOVATION

VOLUME 2 , ISSUE $2,2021,8-25$.

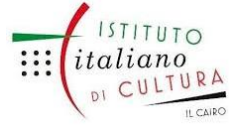

www.egyptfuture.org

/ojs/

completely prevent the growth of all microbial isolates. The result revealed that natural oils could be used to controlling the microbial deterioration of historical books applied with fumigation method. The use of natural oils products will, therefore, reduce over dependence on the use of synthetic chemicals in controlling microbial pathogens as well as reducing cost of management and environmental pollution.

\section{ACKNOWLEDGMENT}

The authors of this paper are thankful to the Microbiology laboratory in conservation center at the Grand Egyptian Museum for helping and providing necessary facilities for this research work.

\section{Conflicts of interest}

The authors declare that there is no conflict of interest.

\section{References:}

[1]Mesquita, N., Nunes, I., Verde, S. C., Bandeira, A. M. L., Carolino, M. M., Portugal, A., Botelho, M. L., 2013. Characterization of an airborne microbial community: A case study in the archive of the University of Coimbra, Portugal, International Biodeterioration \& Biodegradation 79, 36-41.

[2]Nunes, I., Mesquita, N., Verde, S. C., Bandeira, A. M. L., Carolino, M. M., Portugal, A., Botelho, M. L., 2013. Characterization of an airborne microbial community: A case study in the archive of the University of Coimbra, Portugal, International Biodeterioration \& Biodegradation 79, 36-41.

[3]Santos, P.R.V.; Oliveira, A.C.X.; Tomassini, T.C.B.,1995 .Controlemicrobiógico de produtosfitoterápicos. Rev. Farm. Bioquím. 31, 35-38,.

[4]Dahanukar SA, Kulkarni RA, Rege NN., 2000.Pharmacology of medicinal plants and natural products. Indian J Pharmacol.;32:S81-118.

[5]Cowan, MM., 1999. Plant products as anti-microbialagents, ClinMicrobiol Rev.;12:564-82. 
INTERNATIONAL JOURNAL OF

[6]Shaik D, Malika FA, Rafi SM, Naqui B., 1994.Studies of antibacterial activity of ethanolic extract from Nericumindicum and Hibiscus rosasinensis. J Islamic Acad Sci.;7:167-8.

[7]Portugal, A., Mesquita, N., A., Videira, S., Rodrı'guez-Echeverrı'a, A., Bandeira, A.M.L., Santos, M.J.A., Freitas, H., 2009. Fungal diversity in ancient documents. A case study on the Archive of the University of Coimbra. International Biodeterioration \& Biodegradation 63, 626-629.

[8]Montemarini-Corte, A., Ferroni, A., Salvo, V.S., 2003. Isolation of fungal species from test samples and maps damaged by foxing, and correlation between these species and the environment. International Biodeterioration \& Biodegradation 51, 167-173.

[9]Malathy, R. and Shaleesha, A. S., 2015. Studies on the potential therapeutic effects on the aquatic macrophytes namely Cabombaaquatica, Ceratophyllumdemersum and Hygrophilacorymbosa. Journal of Chemical and Pharmaceutical Research 7(4):479483.

[10]El-Hadidi, M. N., 1971. Distribution of Cyperus papyrus and Nymphaea lotus in inland water of Egypt.MitteilungenMünchenerBotanischeStaatssammlungen 10: 470475.

[11]Tackholm, V. V., 1974. Students' Flora of Egypt, 2nd edition, Cairo University Publ., Cooperative Printing Company, Beirut; 888 pp.

[12]Springuel, I. V. \& K. T. Murphy, 1991. Euhydrophyte communities of the River Nile and its impoundments in Egyptian Nubia. Hydrobiologia 210: 35-47. Sridevi, M., Rao, Kondala, Sathiraju, D., 2010. Sensitivity of bacteria isolated from Champavathi Estuary to some medicinal plants of Vizianagaram district, East coast of India. Drug Invention Today 2(7), 366-368.

[13]Shaltout, K. H., A. Sharaf El-Din \& M. A. El-Sheikh, 1994. Species richness and phenology of vegetation along the irrigated canals and drains in the Nile Delta, Egypt.Vegetation 112: 35-43. 
INTERNATIONAL JOURNAL OF

[14]Zahran M.A., 2009. Hydrophytes of the Nile in Egypt. In: Dumont H.J. (eds) The Nile. MonographiaeBiologicae, vol 89. Springer, Dordrecht.

[15]Bushmann, P., Ailstock, M. S., 2006. Antibacterial compounds in estuarine submersed aquatic plants. Journal of Experimental Marine Biology and Ecology $331(1): 41-50$.

[16]Majid, H., Yousuf , T., Ahmad, J., Wanganeo, A. and Raghuvanshi, S., 2017. Antibacterial Activity of some Macrophytes against Fish Pathogens.. International Journal of Scientific and Research Publications7(3):135-137.

[17]Anesini, E.; Perez, C., 1993.Screening of plants used in Argentine folk medicine for antimicrobial activity. J. Ethnopharmacol. 39, 119-128.

[18] Szczepanowska, H., Cavaliere, A.R., 2000. Fungal deterioration of 18th and $19^{\text {th }}$ century documents: a case study of the Tilghman Family Collection, Wye House, Easton, Maryland. International Biodeterioration \& Biodegradation 46, 245-249.

[19]Salem, M.Z.M., Zidan, Y.E., Mansour, M.M.A., El Hadidi, N.M.N., Abo Elgat, W.A.A., 2016. Antifungal activities of two essential oils used in the treatment of three commercial woods deteriorated by five common mold fungi. Int. Biodeterior. Biodegr.106, 88e96.

[20]Chow, S.-Z., 1971. Infrared spectral characteristics and surface inactivation of wood at high temperatures. Wood Sci. Technol. 5, $27 \mathrm{e} 39$.

[21 ]Ajuong, E.-M.A., Breese, M.C., 1998. Fourier transform infrared characterization of Pai wood (Afzeliaafricana Smith) extractives. HolzRohWerkst. $56,139 \mathrm{e} 142$.

[22]Nuopponen, M., Vuorinen, T., Viitaniemi, P., J€ams€a, S., 2003. Effects of heat treatment on thebehaviour of extractives in softwood studied by FTIR spectroscopic methods. Wood Sci. Technol. 37, 109e115.

[23]Aluong, E.-M.A., Redington, M., 2004. Fourier transform infrared analyses of Bog and Modern Oak wood (Quercuspetraea) extractives. Wood Sci. Technol. 38,181e190. 
INTERNATIONAL JOURNAL OF

[24]Nuopponen, M., 2005. FT-IR-and UV Raman spectroscopic studies on thermal (modification of Scots pine wood and its extractable Compounds.Abstract of Doctoral Dissertation. Helsinki Univ. Technol. Lab. For. Prod. Chem. Rep. Ser. A23, 1e29. [25]Salem, M.Z.M., 2016. EDX measurements and SEM examination of surface of some imported woods inoculated by three mold fungi. Measurement 86, $301 \mathrm{e} 309$. [26]Taha, A.S., Elgat, W.A.A., Salem, M.Z.M., Ali, H.M., Fares, Y.G.E., Elshikh, M.S. (2019a). Impact of some plant source additives on enhancing the properties and antifungal activities of pulp made from linen fibers. BioResources 14 (3), 6025-6046. [27 ]Abo Elgat, W.A.A., Kordy, A.M., Böhm, M., Cerný, R., Abdel-Megeed, A., and Salem, MZ,M.: Eucalyptus camaldulensis, Citrus aurantium, and Citrus sinensis Essential Oils as Antifungal Activity against Aspergillus flavus, Aspergillus niger, Aspergillus terreus, and Fusarium culmorum, Processes 2020, 8, 1003; doi:10.3390/pr8081003.

[28]Mansour, M.M.A.; EL-Hefny, M.; Salem, M.Z.M.; Ali, H.M. The biofungicide activity of some plant essential oils for the cleaner production of model linen fibers similar to those used in ancient Egyptian mummification. Processes 2020, 8, 79.

[29]Davies, N.W., 1990. Gas chromatographic retention indices of monoterpenes and sesquiterpenes on methyl silicone and carbowax 20M phases. J. Chromatogr. A 503, 1e24.British Pharmacopeia (1998). (Vol. II). HMSO: London.

[30]Adams, R.P., 1995. Identification of Essential Oil Components by Gas Chromatograph/Quadrupole Mass Spectroscopy.Allured Publishing, Carol Stream, IL.

[31]Das K., Tiwari R.K.S., Shrivastava D.K. Techniques for evaluation of medicinal plant products as antimicrobial agents: current methods and future trends. J. Med. Plants Res. 2010;4:104-111.

[32]MounyrBalouiri, MoulaySadiki, and SaadKoraichilbnsouda , Methods for in vitro evaluating antimicrobial activity: A review, J. Pharm Anal.2016 Apr; 6(2): 7179. 
INTERNATIONAL JOURNAL OF

[33]Satish, S., Mohana, D.C., Ranhavendra, M.P., Raveesha, K.A., 2007. Antifungal activityof some plant extracts against important seed borne pathogens of Aspergillus sp.

J. Agric. Tech. 3, 109e119.

[34]Essa, A.M.M., Khallaf, M.K., 2014. Biological nanosilver particles for the protection ofarchaeological stones against microbial colonization. Int. Biodeterior. Biodegr.94, 31e37.

[35]Mansour, M.M., Salem, M.Z.M., 2015. Evaluation of wood treated with some naturalextracts and Paraloid B-72 against the fungus Trichodermaharzianum: wood elemental composition, in-vitro and application evidence. Int. Biodeterior. Biodegr.100 (C), 62e69.

[36]Mansour, M.M.A., Abdel-Megeed, A., Nasser, R.A., Salem, M.Z.M., 2015. Comparativeevaluation of some woody trees methanolic extracts and Paraloid B-72 againstphytopathogenic mold fungi Alternariatenuissima and Fusariumculmorum. BioResources 10, 2570e2584.

[37]Brantner A, Pfeiffer KP,Grein E (1993) Antibacterial Assays of the Pharmacopoeias: Diffusion Tests of Natural Substances and Their Evaluation. PlantaMedica 59: A675.

[38]Taha, A.S., Salem M.Z.M., Abo Elgat, W.A.A., Ali, H.M., Hatamleh A.A., and Abdel-Salam, E.M. (2019b). Assessment of the impact of different treatments on technological and antifungal properties of produced Papyrus (Cyperus papyrus L.) sheets. Materials 2019, 12, 620;

[39]C. Pasquarella, E. Saccani, G.E. Sansebastiano, M. Ugolotti, G. Pasquariello, R. Albertini, Proposal for a biological environmental monitoring approach to be used in libraries and archives, Annals of Agricultural Environmental Medicine, 19, 2012, pp. 209-212. 
INTERNATIONAL JOURNAL OF

[40]N.Katooli, R.Maghsodlo, S. E. Razavi, Evaluation of eucalyptus essential oil against some plant pathogenic fungi. Journal of Plant Breeding and Crop Science.2011;3(2):41-43.

[41]S.Burt Essential oils: their antibacterial properties and potential applications in foods. Int. J. Food Microbiol.(2004)94:223-253.

[42]Salem, M.Z.M.; Ashmawy, N.A.; Elansary, H.O.; El-Settawy, A.A. Chemotyping of diverse Eucalyptus speciesgrown in Egypt and antioxidant and antibacterial activities of its respective essential oils. Nat. Prod. Res. 2014, 29, 681-685.

[43]Njoroge, S.M.; Phi, N.T.L.; Sawamura, M. Chemical composition of peel essential oils of sweet oranges (Citrus sinensis) from Uganda and Rwanda. J. Essent. Oil Bear. Plants 2009, 12, 26-33.

[44]Barra, A.; Coroneo, V.; Dessi, S.; Cabras, P.; Angioni, A. Chemical variability, antifungal and antioxidantactivity of Eucalyptus camaldulensis essential oil from Sardinia. Nat. Prod. Commun.2010, 5, 329-335.

[45]Dunlop, P.J.; Bignell, C.M.; Hibbert, D.B. Use of gas chromatograms of essential leaf oils to compare clones ofEucalyptus camaldulensis. Biochem. Syst. Ecol. 2000, 28, 383-391.

[46]Bignel, C.M.; Dunlop, P.J.; Brophy, J.J.; Jackson, J.F. Volatile leaf oils of some South-Western and SouthernAustralian species of genus Eucalyptus. Part VII. Subgenus Symphyomyrtus, section exertaria.Flav.Fragr. J. 1996, 11, 35-41.

[47]Giamakis, A.; Kretsi, O.; Chinou, I.; Spyropoulos, C.G. Eucalyptus camaldulensis: Volatiles from immatureflowers and high production of 1,8-cineole and _-pinene by in vitro cultures. Phytochemicals 2001, 58, 351-355.

[48] Devi, K.P.; Nisha, S.A.; Rathinasamy, S.; Pandian, S.K. Eugenol (an essential oil of clove) acts as an antibacterialagent against Salmonella typhi by disrupting the cellular membrane. J. Ethnopharmacol. 2010, 130, 107-115.

[49]Bassolé, I.H.N.; Juliani, H.R. Essential oils in combination and their antimicrobial properties. Molecules 2012, 17, 3989-4006. 


\section{INTERNATIONAL JOURNAL OF ADVANCED SCIENTIFIC RESEARCH AND INNOVATION}

ISSN: 2785-9541
VOLUME 2, ISSUE 2, 2021, 8-25.

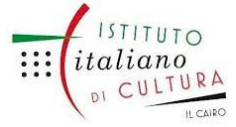

www.egyptfuture.org lojs/

[50]Al-Huqail, A.A.; Behiry, S.I.; Salem, M.Z.M.; Ali, H.M.; Siddiqui, M.H.; Salem,

A.Z.M. Antifungal, antibacterial,and antioxidant activities of Acacia saligna (Labill.) H.

L.Wendl. flower extract: HPLC analysis of phenolic and flavonoid compounds. Molecules 2019, 24, 700 . 